Stanzas in Meditation 
This page intentionally left blank 
Stanzas in Meditation

The Corrected Edition

\section{Gertrude Stein}

Edited by Susannah Hollister and Emily Setina

With an Introduction by Joan Retallack

Yale UNIVERSITY PRESS

NEW HAVEN \& LONDON

In association with the Beinecke Rare Book and Manuscript Library 
Stanzas in Mediation is a co-publication of Yale University Press and the Beinecke Rare Book and Manuscript Library.

Published with assistance from the foundation established in memory of James Wesley Cooper of the Class of I $865_{5}$, Yale College.

Stanzas in Meditation copyright (C) 1956, 20Io Estate of Gertrude Stein. All rights reserved.

Permission to publish facsimiles of materials from the Gertrude Stein and Alice B. Toklas Papers at the Beinecke Rare Book and Manuscript Library was granted by the Estate of Gertrude Stein through its Literary Executor, Mr. Stanford Gann, Jr., of Levin \& Gann, P.A.

“The Impossible: Gertrude Stein” by John Ashbery, copyright (C) 2004 by John Ashbery. Selected Prose (edited by Eugene Richie, University of Michigan Press, 2004, and Carcanet Press Limited, 2004). Review of Gertrude Stein's Stanzas in Meditation (Yale University Press, 1956). From Gertrude Stein Advanced: An Anthology of Criticism, edited by Richard Kostelanetz (McFarland and Co., 1990). First published in Poetry 90, no. 4 (July 1957). Portions were reprinted in A Library of Literary Criticism: Modern American Literature, compiled and edited by Dorothy Nyren (Frederick Ungar, 1960). Reprinted by permission of Georges Borchardt, Inc., on behalf of the author.

Copyright $(C) 2012$ by Yale University. All rights reserved.

This book may not be reproduced, in whole or in part, including illustrations, in any form (beyond that copying permitted by Sections Io7 and Io8 of the U.S. Copyright Law and except by reviewers for the public press), without written permission from the publishers.

Yale University Press books may be purchased in quantity for educational, business, or promotional use. For information, please e-mail sales.press@yale.edu (U.S. office) or sales@yaleup.co.uk(U.K.office).

Designed by Mary Valencia.

Set in Adobe Caslon type by Keystone Typesetting, Inc.

Printed in the United States of America.

Library of Congress Control Number: 2011924246

ISBN 978-0-300-I5309-5 (paperback : alk. paper)

A catalogue record for this book is available from the British Library.

This paper meets the requirements of ANSI/NISO Z 39.48 - 1992 (Permanence of Paper).

IO 987665432 I 